\title{
ONLINE MEDIA AND INTERCULTURAL COMMUNICATION
}

\author{
UDC 316.77: [070:004.738.1
}

\author{
Marija Vujović, Neven Obradović \\ University of Niš, Faculty of Philosophy, Deparment of Communicology and Journalism, \\ Serbia
}

\begin{abstract}
The emergence of the Internet has led to tectonic changes in all aspects of human life, and certainly the most important ones occurred in communication and information. The term "Global Village", which was first used by Marshall McLuhan in his "Report on the project of understanding new media" in 1960, seems to be more current today than ever. The emergence of online media, social networks and many other applications has enabled people to connect and communicate no matter where they are on the planet. However, despite all the positive effects that communication networks have brought with them, there are many negative aspects of intercultural communication that have been retained to the same or even greater extent, creating the so-called "noise" or disruption of communication. One of the best examples of this is the comments in the online media. This an essential segment of online journalism, and it proved to be a fruitful intercultural communication channel, which is why this paper will put special emphasis on the readers' comments.
\end{abstract}

Key words: online media, intercultural communication, comments, information

\section{INTRODUCTION}

Based on the latest data provided by the International Telecommunication Union, the World Bank and the United Nations, just a little under 3 and a half billion people, or about $46 \%$ of the world population, have Internet access from their homes. ${ }^{1}$ Billions of users of the network of all networks have made the Internet "the centre of global market of information and trade" (Craig 2010, 11). A high speed network of high flow, which was only a prognosis in the mid-nineties (Herman and McChesney 2004, 200), has become a reality in the majority of the world, which, as it seems, has provided the Internet with unlimited power.

Received December 10, 2016 / Accepted December 30, 2016

Corresponding author: Marija Vujović

University of Niš, Faculty of Philosophy, Ćirila i Metodija 2, 18000 Niš, Serbia

E-mail: marija.vujovic@ filfak.ni.ac.rs

${ }^{1}$ Precise data available at the following link: http://www.internetlivestats.com/internet-users/ (Accessed on 4/6/2016) 
"The president of Google's board of directors Eric Schmidt estimates that it would take 5 billion gigabytes of memory space to digitally record all survived human achievements and the information generated from the beginning of time until 2003. In 2010, people were generating that much data every two days. In 2012, the amount of video material uploaded on YouTube doubled in comparison to 2010 and thus reached the amount of data that corresponds to the duration of 180,000 fulllength films a week" (McChesney 2015, 2). ${ }^{2}$

The internet and software companies are among the most successful companies in the world. Robert McChesney says that four out of ten most successful companies in the US in 2012 were Apple, Microsoft, Google and AT \& T, but Apple ranks first (McChesney 2015). In support of the story about the power of these companies, we should mention the contract which was signed in May 2016 between Facebook and Microsoft about laying the biggest transatlantic Internet cable in the world (with a length of $6600 \mathrm{~km}$, with a flow of 160 terabytes per second), which will connect Northern Virginia (USA) and Bilbao (Spain) and enable the fastest possible internet connection to their customers in the US and Europe. In this way, the big internet giants are becoming independent of the telecommunications companies that manage Internet connections. ${ }^{3}$

"According to IMS Research, approximately 22 billion devices will be connected to the internet and will communicate online until 2020. [...] Mobile communication, says a World Bank report from 2012, probably had a greater impact on humanity in a shorter period than any other invention in history" (McChesney 2015, 3).

The communication "big bang", which brought with it the Internet of large flow has fundamentally changed communication and information sharing in modern society. Social networks and other related applications on smartphones have transformed their users into online entities available 24 hours a day, networked into McLuhan's "global village" (McLuhan 1960), ${ }^{4}$ but all this can be the subject of a separate paper. What interests us in this case is information sharing via online media and its role in intercultural communication. Online media, it seems, can no longer be called new media. The mere fact that there genres already exist, ${ }^{5}$ as do rules of writing, ethical standards and jurisdiction of ethical and other regulatory media over online media speaks in favour of them having entered the ranks of the "great ones" or as they are better known in theory, the traditional media.

Online Journalism "was crowned" during the terrorist attacks on New York and Washington in 2001. The latest information would appear minute after minute, "two basic human needs - to gain support at the time of tragedy and to share information about it - led the press organizations and citizens to use online news at the previously inconceivable proportions" (Craig 2010, 19). Online media have completely changed the

\footnotetext{
${ }^{2}$ More specifically, in less than a week, YouTube generates more content than all the films and TV programs that Hollywood produced during its entire existence (McChesney 2015).

${ }^{3}$ The entire text is available at the following link: http://finance.yahoo.com/news/microsoft-facebook-buildinnovative-subsea-170700216.html (Accessed on 4/6/2016)

${ }^{4}$ The entire McLuhan „Report on the project of understanding new media“ is available at the following link:http://blogs.ubc.ca/nfriesen/files/2014/11/McLuhanRoPiUNM.pdf (Accessed on 4/6/2016)

${ }^{5}$ Neda Todorović suggests a new division of journalistic genres, adapted to the online sphere and psuedo journalism, based on which genres are divided into: factual (reporting journalism) and interpretative (investigative journalism). Noting that this division is conditional, because at this moment overall hybridization of genres is taking place (Todorović 2013, 29).

${ }^{6}$ CNN Webpage, as the precursor of today's live online coverage: https://web.archive.org/web/20010911200318/ http://www.cnn.com/ (Visited on 5/6/2016)
} 
attitude of the public towards information. "Multimedia nowadays provides so many opportunities and is used in so many new ways which means that traditional reporting has dramatically changed. The audience simply requires more" (Craig 2010, 24). Information from all over the world is available in real time, with the simultaneous transmission of video and other multimedia content. The study, which was conducted in 2009 by the "Centre for the global information industry, has shown that an average American consumes information 11.4 hours a day, as opposed to 7.4 hours in 1980" (McChesney $2015,2)$. The availability of information greatly facilitates intercultural communication because we have the opportunity to learn more about other cultures and peoples. As pointed out by Herman McChesney, the most surprising fact is that this "looks just like the beginning. Finally, at least theoretically, all people could become interconnected at speeds approaching the speed of light, and they could be able to transmit and receive various communication messages with instant access to the whole human culture" (McChesney 2015 , 3). However, it should be noted that in this ocean of information, which we are provided or will be provided by the "network of all networks" lies the potential "noise" that often disturbs any type of communication, including the intercultural one. In addition to current information provision, online media provide the audience with full interaction, and as claimed by Richard Craig, this is exactly what "most clearly illustrates the difference between online media and all other media; online journalists believe that their media has a greater degree of mutual relationship with the audience" (Craig 2010, 46). Comments in online media proved to be an important platform for communication with journalists, but also for exchange of opinions among readers. Due to this fact, we will pay special attention to this segment of online media, because comments in online media are very often an excellent example of intercultural communication.

\section{ONLINE MEDIA}

For online media and online journalism in general, the year 1994 and the emergence of the browser Netscape Navigator is of historical importance ${ }^{7}$. Thanks to the graphic interface of the browser, online information became available to Internet users. "Websites with news soon found themselves among the most visited sites on the network. [...] For the then existing press organizations, opening web pages became a major task. According to the American Journalism Review, in 1994 only 20 newspapers worldwide had Websites. After less than 5 years, more than 5000 had them" (Craig, 2010: 25). New opportunities in reporting, such as multimedia and the current update of the story with the most recent information, suddenly increased the number of visitors to online media. Research of the Pew Research Center in the United States from 2010 shows that 71 percent of Internet users, or 53 percent of adult Americans are informed via online media. ${ }^{8}$

Josef Dominick defines four types of online media. The first type are mainstream news media, such as CNN or USA Today, which offer text, audio and video materials in several sections, such as national news, world news, technology, sports. The equivalent in

\footnotetext{
${ }^{7}$ The appearance of Netscape Navigator with an overview on the most important news from 1996 can be seen at the following link: https://web.archive.org/web/19961126184740/http://www29.netscape.com/ (Visited on $5 / 6 / 2016)$

${ }^{8}$ Results of the research are available at the following link: http://www.pewinternet.org/2010/03/15/the-economicsof-online-news/ (Visited on 5/6/2016)
} 
our country is the web site of daily newspaper Blic, and B92 and N1 television. The second group includes news generators like Google or Yahoo!, which offer an overview of news from multiple sources and regularly introduce the most important news. In our country, similar news generators to these would be Naslovi.net and Vesti.rs. The third type is specialized online media, which offer a focus on a particular field of information; Dominick here mentions the Wall Street Journal which specializes in reporting on finance and business, and ESPN.com which specializes in sport. In Serbia, this category can include specialized sports portals such as Sportska centrala, HotSport, MVP.rs. According to the US author, the last category involves blogs, which have become an influential force in online reporting, but at the same time questions need to be asked about the quality and ethical standards which blogs (do not) have to comply with (Dominick 2009, 298). Online journalism has the "doors wide open for the possibilities of interactive communication, personal creations of readers and listeners; viewers are no longer restricted only to feedback, or to a mere consumer reaction to the published content, they are now together with the author witnesses of events, sources of information on the spot, they all share the same job, getting a role in the creation of journalistic products and in the making of news" (Todorović 2013, 21).

Online media have consolidated into one everything that traditional media had to offer. "It has the ability to process the information in detail the same as press does, it offers the immediacy of television by instantly providing the latest data and audio and video recordings, and it has a unique ability to take users to websites where they will be able to read more about topics of interest to them" (Craig 2010, 33). Choice is one of the biggest advantages of online media, which is why the media must always give more in terms of the quality of information, but also design and flexibility to readers. "The online audience is known as picky and inconsistent. Users would regularly indicate that they were more than willing to replace one source with another if this new source would provide information more quickly or in a more convenient format" (Craig 2010, 31). An important feature of online media is choice. Consumers are not obliged to be informed via the media imposed by the broadcasting spectrum, cable operator, or printed media. This is an important component for the development of intercultural communication. Online media allow us to "peek" over the borders of our community, to be informed about the society or culture in other countries directly via the media of that country. Thanks to this freedom of choice when it comes to sources of information, online media have become a kind of an informative bridge between nations and cultures. However, so many sources carry with them problems, "legal statement of many national legal regulations according to which any physical or legal person is allowed to create the media and to use them for the free flow of information, has become a reality. An abundance of these individual initiatives has already led to congestion in the sphere of information" (Veljanovski 2010, 46). We are witnessing an almost daily "birth" of a new online media, which backed by social networks, that is, users who are not literate enough, gets published and false information is usually adopted as true thanks to the "share" option.

Such information contributes to informative saturation and makes selectivity difficult, while selectivity should be available because it should lead to that form of awareness that complements the public sphere, as a sphere of the citizens. The problem of responsibility for the contents to be displayed to the public is therefore inevitable and requires a regulatory framework, as well as other forms of media expression" (Veljanovski 2010, 47). Unregulated online media enables virtually uncontrolled penetration of unverified, 
inaccurate or even malevolent fictitious information into the public sphere. This way of placing information may seriously threaten intercultural communication. This may be particularly devastating to regions such as the former Yugoslavia, where media literacy is at a low level and where citizens are susceptible to media manipulation. Memories of the media preparation of war and ultranationalist hikes during the 1990's are still fresh. Uncontrolled online news may not lead to a similar phenomenon, but in any case, it can lead to the establishment or deepening of antagonism among the peoples of the Balkans created during the 1990's.

Thus, the regulated online information field based on the principles of professional journalism and respect for ethical norms, with the expansion of media literacy and education to the public and journalists can be a powerful impetus for successful intercultural communication.

\title{
3. INTERCULTURAL COMMUNICATION AND THE SPHERE OF ONLINE MEDIA
}

Intercultural communication represents the conditio sine qua non of modern society, cultural heterogeneity caused by large immigrant waves, caused by the war across the globe, as well as economic conditions which cause the daily encounters and communication between members of different cultures.

\begin{abstract}
"The basis for the distinction between intercultural and intracultural communication is the degree of homogeneity, or heterogeneity of the participants. It is actually a continuum whose extremes are ideal types, that is, realistically non-existent situations. On one hand, there are completely homogeneous communication participants whose communication is intracultural, and on the other hand, there are completely heterogeneous participants whose communication has all the characteristics of interculturalism. In the social reality, this phenomenon of extremely conflicting and confusing discontinuous poles is replaced with a continuum consisting of groups whose cultures are different" (Stojković 2002, 27).
\end{abstract}

Cultural heterogeneity caused by the above global changes forces us to get to know other and different things, which the Internet and online media facilitate immensely. Being better informed makes it easier for the modern man to communicate, because the experience that is a prerequisite for the establishment of communication is available online. "As the zone of common experience expands compared to the overall experience of each individual participant in communication, communication becomes easier and vice versa - a minimum of common experience equals the minimum possibility for communication" (Stojković 2002, 28). Joseph Schmitz emphasizes that the electronic media have great potential for bridging the "abyss" separating groups and persons, which is defined by Blau. The boundaries can be: "1) spatial; 2) temporal; 3) perceptive; 4) psychological”, according to Schmitz, "electronic communication systems have great technical potential to allow geographically separate but socially similar users to exchange information asynchronously and bridge the previously described boundaries" (Schmitz 2001, 135).

"Thanks to the international exchange of cultural goods - news, video clips, books, films, radio, television programs, newspapers, etc., man of this age is able to create extensive cognitive map of the world. Whether the modern man wants it or not, he gets to know better other peoples and cultures, thus a sense of belonging to the international community and postmodern civilization is more or less strengthened" (Radojkovic, Stojković, Vraneš 2015, 37). 
Online media, who are guided by the principles of the journalistic profession can be an important element of intercultural communication, and because of their accessibility to a wide audience they can play the role of what France Vreg called transcultural mediators. Such online media would be

\begin{abstract}
"able to conceive and develop processes of mutual communication. This is a type of tolerant dialogue, and also reasoned discussions and scientific communication. [...] Initiated processes of transcultural mediation are possible to be continued in politics, and in all other aspects of social life. Publicist sphere should primarily need to show professional responsibility; it should leave behind authoritarian methods of journalistic activities and accept the paradigm of democratic communication" (Vreg 1991, 296).
\end{abstract}

The online sphere "unlocks the gates of paradise when it comes to research. Journalists worldwide have access to data, archives, primary and secondary sources. Such access is not only granted to them, some topics have actually become accessible to others; topics that were previously exclusive or disseminated to the public as a rumour can now be controlled by the audience to some extent" (Rus-Mol 2005, 160). Freedom of information leads to an open system of a society, and according to Vreg, this openness "is the confrontation of a system with other (developed or less developed) systems in a competitive position: the inflow of diversity into the system triggers the 'tension' of the system and can be an incentive for its own creativity" (Vreg 1991, 278). From this perspective, the online media are an important factor in preventing the closure of a society, which is also discussed by Jelenka Voćkić Avdagić, "cultural pluralism, in terms of coexistence and communication of different cultures, could be a way to prevent their closure and to prevent a lack of understanding in the process of communication based on the values of "other people's" culture" (Voćkić-Avdagić 1997, 107). Online media in combination with social networks facilitate global communication between nations, provided there is objective and ethical information sharing, thus narrowing down the above-mentioned experience that is a prerequisite for establishing communication. According to Danko Plevnik, "all human societies must prefer communication, and not information isolation, because lack of communication today can lead to "excess of catastrophe" tomorrow" (Plevnik, according Voćkić-Avdagić 1997, 106).

At this point it is necessary to ask a question about the other side of the coin - how come that with all the opportunities we have for free communication and information offered by the Internet, we still have an "excess of catastrophe". Wars, terrorism, human rights violations, the polarization of the world are our reality. "From the promise of radical democratization of the public sphere, a true media pluralism, decentralization of social power, the disappearance of censorship, de-commercialized culture and market without monopolies, we ended up with a completely different picture. Internet communication space is concentrated in the "clouds" of a few monopoly corporations" (McChesney 2015). The telecommunications Act passed in the US in 1996 envisaged the deregulation of the Internet by the state, and instead of freedom, another "re-regulation followed strictly to serve the interests of large corporations" (McChesney 2015, 135). Internet giants comfortably leaning back in the saddle of capitalism", are galloping towards their goal - the "planetary homogenization of culture" (Stojković 2002, 230), which will give them unlimited power.

\footnotetext{
9 "Google holds $70 \%$ of the Internet browsing market, $97 \%$ of the growing mobile browsing market, Microsoft's operating system "Windows" is still used on more than $90 \%$ of all computers. It is estimated that over iTunes,
} 
"Mark Zuckerberg from Facebook was invited to the 2011 meeting of G8, where he sat at the table and discussed world politics. MacKinnon describes "Facebookistan" and "Googledom" as virtual national states obsessed with limiting the ability of governments to interfere in their profitability and growth, which are their main interest. The US government - the same one that theoretically works to regulate the business of giants in the country - generally operates as their powerful global advocate" (McChesney 2015, 184).

Branimir Stojković believes that the response to the attempt of universalization is the trend of growth of regionalism and nationalism in the world: "Positive and negative effects of more and more intensive international communication seem to be reduced to zero sum game - essentially, they cancel each other out. [...] In support of both theses a great number of books have been written, whose arguments oppose each other, but the final and irrevocable answer is still not in sight" (Stojković 2002, 231).

\section{COMMENTS In ONLINE MEDIA As A TYPE OF INTERCULTURAL COMMUNICATION}

Contact with the audience is one of the most important segments in online journalism. "Interaction provides so quick a feedback which was previously unimaginable" (Craig 2010, 47). The feedback from the readers is an important source of information for online journalists, but also represents a new kind of media content, which attracts great attention from the audience. "Interactivity really means sharing power. This means giving up the role of the leader in decision-making on the agenda. This means letting readers comment on your version of the events" (Craig 2010, 48). "An ordinary man is given the opportunity to create the messages, to distribute them to the others, but also to compete with professional creators of public opinion, indirectly participating in the shaping of reality images" (Jevtović and Aracki 2014, 320). In addition to interacting with journalists and editors of online media, comments take on the role of the forum in online media, and provide a platform for the confrontation of opinions and attitudes, and as such are a perfect field for intercultural communication. On the Internet it is possible to find lots of both positive and negative examples, that is, the development of intercultural communication, as well as hate speech and lack of understanding of others and different individuals.

In the international online edition of the magazine National Geographic, on March 9, 2016, a report was published on Mardi Gras Indians and their festival in New Orleans. ${ }^{10}$ It is a festival where the local African-Americans and Mardi Gras Indians dress up in Indian costumes, as a sign of gratitude for mutual assistance in persecution and the struggle for equality. ${ }^{11}$ Under the article, in the comments section, communication started which is an excellent example of intercultural communication and learning about other cultures and different peoples. Besides the comments where readers of other cultures

Apple controls $87 \%$ of music downloading market and $70 \%$ of the software market for playing video material. [...] In 2012, Apple had in their cash register 110 billion dollars of cash, Google had 50 billion dollars, Microsoft had 51 billion, Amazon had 10 billion, Facebook 16 billion“ (McChesney 2015, 166, 174).

${ }^{10}$ Mardi Gras Indians adopted this name after the natives in gratitude for their help in escaping the tyranny of slavery. Later, during the war for freedom of African-Americans, mostly in New Orleans, the local Indians accepted slaves into their communities after these gained freedom. They never forgot their support.

${ }^{11}$ Entire text and comments available at the following link: http://intelligenttravel.nationalgeographic. com/2016/03/09/the-secret-history-of-new-orleans-mardi-gras-indians-super-sunday-saint-josephs-day/ (Accessed on $9 / 6 / 2016$ ) 
were thrilled with the article, the festival itself and the opportunity to learn about the culture and customs of the Indians, there was a constructive intracultural debate on whether Indians should do public performances. A reader, who identified herself as an Indian, registered as Jacqueline, from Kalamazoo in the state of Michigan, put forward the view that Indians should not do public performances, because it is a spiritual thing which can be carried out only within the tribe or family. This comment was followed by another one from a reader registered as Troy, from the city of West Monroe, in the state of Louisiana, who identified himself as an Indian, and expressed a view that such things are necessary, that such things keep the very culture of the Native Americans, and that if she had the opportunity to attend Mardi Gras Indian gatherings, she could have certainly seen how much spirituality these performances involve, emphasizing that such festivals preserve the tradition of the Indians. This example clearly shows us a positive example of intercultural communication, but also of intracultural communication that gives a completely new angle to the story and provides a better understanding of Indian culture. It originated precisely from the possibility that ordinary people through interactivity and comments create a new text in addition to the journalist's article.

A completely opposite example is the article on the Huffington Post website titled "Iran punished students with 99 lashes for unauthorized graduation party". ${ }^{12}$ The text itself is problematic from the aspect of cross-cultural communication, as the journalist emphasizes that students were punished for "dancing with persons of the opposite sex and alcohol consumption." In Western culture, such behaviour is an integral part of the lives of young people, while in this country it is strictly forbidden due to strict religious customs. It was absolutely expected that the insistence that some things that are allowed in Western countries are actually prohibited in Iran without a deeper cultural analysis would lead to comments that violate intercultural communication. That was exactly what followed. What is interesting about the Huffington Post portal is that the comments linked to Facebook profiles can be anonymous only if the user has a "fake" profile, but if this is not the case then real people stand behind the comments. Carol Hollenbeck from New York left a comment under this article which read: "This is the only religion in this century that is so retrograde; I wonder whether women had a mask during the flogging." Then we have a comment by Steve Cherry, stating that young people in Iran must start a revolution, similar to the one in 1979, to overthrow the repressive regime. This way of reporting creates problems in intercultural communication, and creates stereotypes about other cultures. This is supported by the comment of the reader under the name Mukarama Sied from Chicago, ${ }^{13}$ whose profile clearly shows that he is a member of the Islamic religion, stating that the sentence from the article which reads: "Alcohol and dancing with persons of the opposite sex are prohibited in Iran, especially if a woman does not wear the Islamic veil" is a tendentious reporting and he noted that insistence on the prefix "Islamic" in front of the word "veil" can in no way make it more important than drinking alcohol or dancing with persons of the opposite sex, which are equally prohibited by religious law. He also emphasizes that if a journalist criticizes the system of another

\footnotetext{
${ }^{12}$ The entire text and comments are available at the following link: http://www.huffingtonpost.com/entry/iranpunishes-partying-college-students-99-lashes_us_57486df7e4b055bb1171fa01?cps=gravity_5020_-4526651404 80037275 (Accessed on 9/6/2016)

${ }^{13}$ The profile is available at the following link: https://www.facebook.com/mukarama.syed (Accessed on 9/6/2016)
} 
country, without an adequate cultural approach, it is necessary to at least offer a precise analysis.

Because of all the events during the 1990's, the situation in the former Yugoslav countries is extremely complicated in this segment of online journalism. Intercultural communication is based mainly on hate speech and mutual accusations for the war. Brankica Drašković conducted a survey on the topic of online comments on the most visited portals in Serbia and Croatia (Blic and Jutarnji list) for a period of three months in 2012. The results were utterly devastating. "In-depth analysis of the comments showed a severe distance between "us" and "them" grouped into national groups from which they glorify their own nation thus encourage a development of a negative political and ethnic otherness.[...] Nearly all the comments come down to highlighting the differences and denying the similarities and stating that "we are not what they are". All that happened in the war is difficult to admit and even harder to accept; each side attempts to defend themselves from the other side thus tries to reduce their own and increase other people's guilt. In this collective "liberating and denying" climate, all those who do not speak the language of (agree with) the group are declared traitors" (Drašković 2014, 351, 357). What is particularly worrying is that it is almost impossible to find a topic in online media where hate speech is not dominant. An interesting example is the tennis player Novak Djokovic, who is always seen as a fair sportsman and to whom perhaps the following sentence that was once uttered by the world champion in boxing Mate Parlov best applies to: "I cannot be a nationalist, I'm a world champion". Hate speech is also a dominant part of the comments of articles related to his victory. Celebrating his victory, "commentators" from Serbia seize the opportunity to provoke other nations, while "others" exclude Djokovic when it comes to the offenses, but they take the opportunity to provoke and insult the Serbian people. ${ }^{14}$

\section{CONCLUSION}

It is a general impression that in all segments of the online sphere, even in the field of online media, there are more problems that seriously damage relations in modern society than positive things that contribute to its progress. Do we have a solution? It is possible that we do not have one now, but it seems that we do know which road to take to get to it. That road is education. Media literacy, but also education about the economy and democracy are essential for the future of humanity. As pointed out by Robert McChesney, a crisis of our time is linked with the fact that capitalism undermines democracy; he also believes that we are at a crucial moment now, where we need to decide whether to expand democracy or not, but he notes that this requires dealing with the real existing capitalism. "Battles over the Internet are of crucial importance for all those who seek to build a better society. When the dust settles of this critical and epochal moment, and if then our societies are not transformed for the better, if democracy did not defeat capital, the digital revolution could prove to be a revolution in name only, and it could only be a tragic reminder of the growing gap between the potential and the reality of human society" (McChesney 2015, 298). In order to avoid almost tribal divisions in the Balkans, but also

\footnotetext{
14 An example where the conclusions are clearly visible is available at the following link: http://klix.ba/sport/ tenis/noletova-proslava-postao-kralj-nacrtao-kuertenovo-srce-i-legao-u-njega/160605072\#komentari (Visited on 9/6/2016)
} 
in many other parts of the world, in a world where communication-wise we have never been so closer, it is critical to include media literacy, both for the young and the elderly. Skills such as critical thinking and self-expression are crucial for the democratic functioning of citizens. "Media literacy should encourage citizens from an early age to put pressure on the media looking for quality information and professionalism of journalists" (Zuber 2015, 490). Better information sharing is a prerequisite for better intercultural communication among people. We live in a time of great freedom of information and education, but it seems that we have never been more slaves, slaves of ignorance. Thomas Friedman, a columnist for The New York Times, said that "at its best, the Internet can educate the largest possible number of people faster than any other media so far. At its worst, it can make people dumber than any media that we have had. Because the Internet has a sort of a "technology aura", uneducated people believe the information coming from the Internet even more. They do not realize that at its worst, the Internet is open sewerage for unverified and false information" (Seib 2008, 61).

\section{REFERENCES}

Dominick, Joseph. The Dynamics of Mass Communications. New York: McGraw-Hill, 2009.

Drašković, Brankica. Nacionalistički diskurs i predstave o drugomu komentarima čitalaca. U Uloga medija u normalizaciji odnosa na Zapadnom Balkanu, 341-362. Novi Sad: Filozofski fakultet u Novom Sadu, 2014.

Herman, Edvard i Robert Mekčesni. Globalni mediji. Beograd: Clio, 2004.

Jevtović, Zoran i Zoran Aracki. „Moć glasina i dezinformacija u kreiranju moralne panike na onlajn društvenim mrežama". U Internet i društvo, uredili Dragan Todorović, Dalibor Petrović i Dragan Prlja, 319-336. Niš i Beograd: Srpsko sociloško društvo, Filozofski fakultet u Nišu i Institut za uporedno pravo, 2014.

Krejg, Ričard. Onlajn novinarstvo. Beograd: Clio, 2010.

McLuhan, Marshall. Report on Project in Understanding New Media. National Asociation of Electronical Broadcasters, 1960. Link: http://blogs.ubc.ca/nfriesen/files/2014/11/McLuhanRoPiUNM.pdf

Mekčesni, Robert. Digitalna isključenost - Kako kapitalizam okreće internet protiv demokratije. Beograd: FMK, Multimedijalni institut, 2015.

Radojković, Miroljub, Branislav Stojković i Aleksandar Vraneš. Međunarodno komuniciranje u informacionom društvu. Beograd: Clio, 2015.

Rus-Mol, Štefan. Novinarstvo. Beograd, Clio, 2005

Seib, Philip. The Al Jazeera Effect. Washington D.C.: Potomac Books, 2008.

Stojković, Branislav. Identitet i komunikacija. Beograd: Fakultet političkih nauka, Čigoja štampa, 2002.

Šmic, Džozef. „Strukturne relacije, elektronski mediji i društvena promena: javna elektronska mreža i beskućnici”. U Virtuelna kultura - identitet i komunikacija u kiber-društvu, ur. Stiven Džouns, 127-159. Beograd: Biblioteka XX vek, 2001.

Todorović, Neda. „Prilog teoriji žanrova u postnovinarstvu“. Medijski dijalozi 17 (2013): 11-44.

Voćkić-Avdagić, Jelenka. Razvoj savremenih komunikacijskih procesa $i$ sistema $i$ bosanskohercegovačko društvo i država. Sarajevo: Fakultet političkih nauka, 1997.

Vreg, France. Demokratsko komuniciranje. Sarajevo: Narodna i univerzitetska biblioteka i Fakultet političkih nauka, 1991.

Zuber, Ljubomir. „Medijska pismenost - put ka slobodnijoj komunikaciji”. U „Nauka i sloboda“, 479-492. Istočno Sarajevo, Pale: Filozofski fakultet, 2015. 


\section{ONLAJN MEDIJI I MEĐUKULTURNO KOMUNICIRANJE}

Pojava interneta dovela je do tektonskih promena u svim sferama ljudskog života, a sasvim sigurno ona najznačajnije desile su se u komunikaciji i informisanju. Pojam , Globalnog sela “koji je prvi put upotrebio Maršal Makluan u svom „Izveštaju o projektu razumevanja novih medija“ 1960. godine, čini se da nikada nije aktuelniji nego danas. Pojava onlajn medija, društvenih mreža i niza drugih aplikacija omogućila je povezivanje i komunikaciju ljudi bez obzira gde da se nalaze na planeti. Međutim i pored svih pozitivnih efekata koje su sa sobom donele mrežne komunikacije, mnogi negativni aspekti međukulturne komunikacije zadržali su se i istoj ili čak većoj meri stvaraju takozvane „šumove“ ili prekide komunikacije. Jedan od najboljih primera za to jesu komentari na onlaijn medijima. Ovaj neizostavan segment onlajn novinarstva, pokazao se kao plodonosan kanal međukulturne komunikacije, zbog čega će poseban akcenat u ovom radu biti upravo na komentarima čitalaca.

Ključne reči: onlajn mediji, međukulturno komuniciranje, komentari, informisanje 